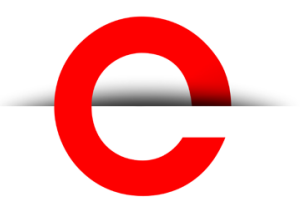

U T S

e PRES S

\section{PORTAL Journal of Multidisciplinary} International Studies

Vol. 13, No. 2

July 2016

Designing Futures in Indonesia, Curated Works Special Issue, Curated by Alexandra Crosby.

\section{(c) (1)}

(C) 2016 by Clare M. Cooper. This is an Open Access article distributed under the terms of the Creative Commons Attribution 4.0 Unported (CC BY 4.0) License (https:// creativecommons.org/ licenses/by/4.0/l, allowing third parties to copy and redistribute the material in any medium or format and to remix, transform, and build upon the material for any purpose, even commercially, provided the original work is properly cited and states its license.

Citation: Cooper, C. M. 2016. Collective Improvisation. PORTAL Journal of Multidisciplinary International Studies, 13:2, 1-6. http://dx.doi. org/10.5130/portal.v13i2.5048

ISSN 1449-2490 | Published by UTS ePRESS I http://portal. epress.lib.uts.edu.au
CURATED WORK

\section{Collective Improvisation}

\section{Clare M. Cooper}

Department of Media Music Communication and Cultural Studies, Faculty of Arts, Macquarie University

Corresponding author: Claire M. Cooper, C/o Frontyard, 228 Illawarra Rd, Marrickville NSW 2204, Australia. clareagutstring.net

DOI: http://dx.doi.org/10.5130/portal.v13i2.5048

Article History: Received 20/06/2016; Revised 27/06/2016; Accepted 11/07/2016;

Published 09/08/2016

\section{Abstract}

Collective improvisation as a creative practice is intensely social, trusting, unpopular, anti-hierarchical and, for these reasons, political. Cooper describes the risks and rich rewards of improvising with fellow artists and identifies the parallels between improvising ensembles of musicians in Australia with the collectively painted protest banners of the Taring Padi Collective in Indonesia after a brief visit to Jogjakarta.

\section{Keywords}

Improvisation; Indonesia; Collectives; participation; collectivity; experimental art 
U T S

e PRES S

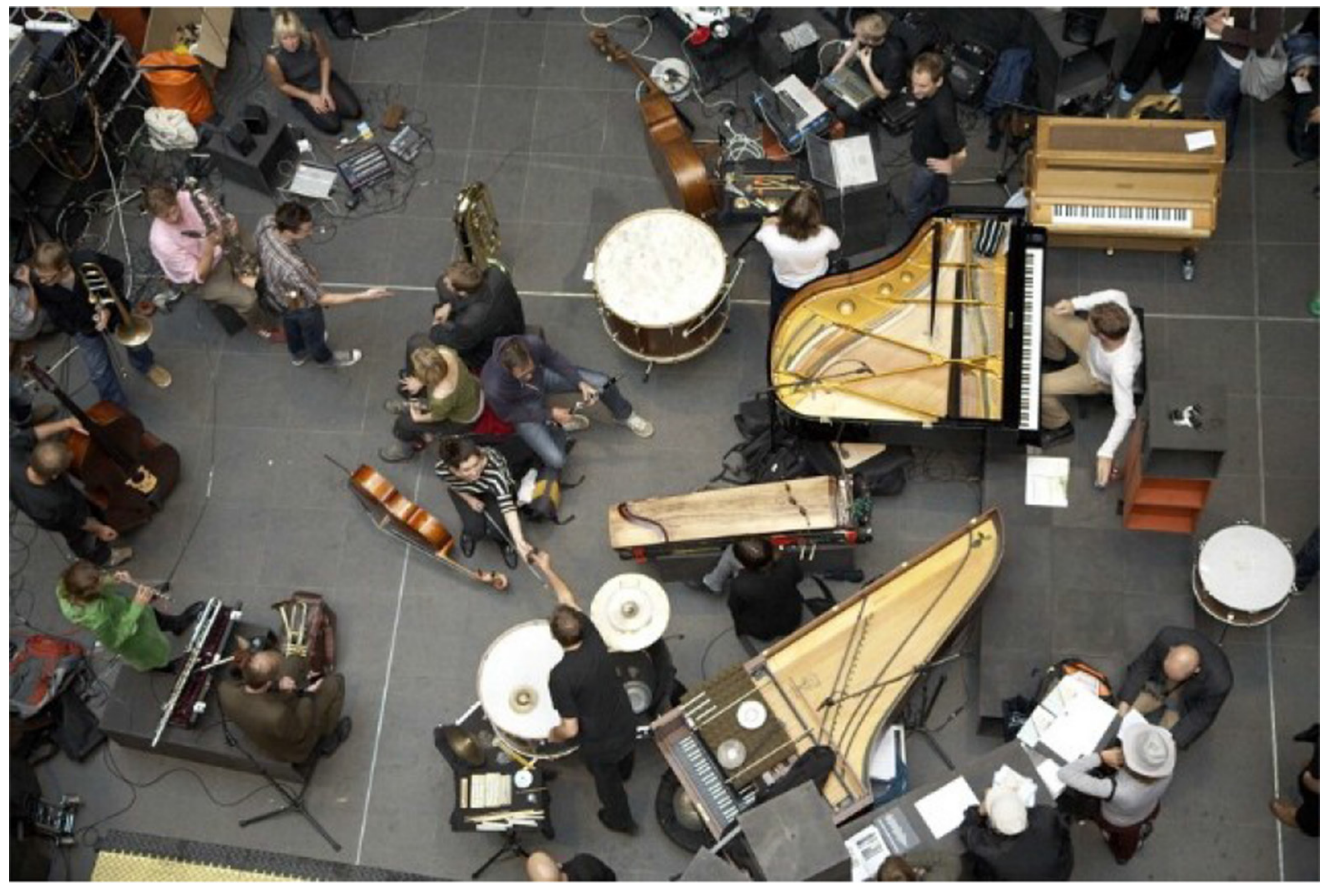

Figure 1 Berlin Splitter Orchester plays Hauptbanhof (Berlin Central train station) (c) G. Hotz, 2012

The fraught, unknown social dynamics of group work is the most terrifying prospect for my Interdisciplinary Design Studies students at the University of Technology Sydney. They are encouraged to improvise collectively, to risk, to fail fast, to observe one another's technical, social, imaginative and philosophical strengths and to create with a combined palette. There is no score. No conductor. There is no pre-definition of what will work. Leaders emerge from these groups, but mostly the groups create a level playing field.

This kind of collective improvisational work is high risk and incredibly rewarding. It has formed the basis of my creative practice as a musician, designer and activist over the past sixteen years.

Collective improvisation as a creative practice is intensely social, trusting, unpopular, anti-hierarchical and, for these reasons, political. We improvise to be present. To embrace risk and failure over pre-determined results. When we perform our collective improvisations with no prior planning or risk management strategy or foreseeable (profitable) outcome, we are publicly stating that we trust one another. From experience, we've found that this trust, our combined risk and a recognition of shared, unique moments are worth the potential public falterings, humiliations and failures.

We learn together. We become more patient, more compassionate and less focused on the idea that there is ever a single, perfect outcome. These learnings have not only informed my music, but the way I move through and appreciate the world.

Large-scale improvising ensembles such as the Scratch Orchestra (UK, 1969-1974), AACM (USA), Sun Ra Arkestra (USA), and the Globe Unity Orchestra (Germany), have all valued the voice of the group over the individual and have prioritised the creative freedom of their members. Some of these ensembles have committed to improvising together over decades, some combine pre-composed structures with spontaneous play, others have a fluid membership — at times taking on a more pedagogical role for those entering into collective improvisation for the first time. 
U T S

e PRES S

Carving out new depths of performability and listenability serves to expand the soundscape of society - from background musak in elevators to the kind of noise music that agitates, angers or inspires political action.

I have co-founded two large-scale improvising ensembles: the Splinter Orchestra (Sydney, 2002-current), which has had a fluid line-up of 15-50 players and is made up from the community that congregated around the NOW now festival of improvised music and experimental film (Sydney, annual festival and semi-regular series 2001-current); and the Splitter Orchester (Berlin, 2010-current), which has a consistent membership of 25 Berlinbased composer-performers from ten countries. Co-founders Clayton Thomas, Gregor Hotz and myself invited active musicians from the prolific Echtzeitmusik scene, a locally based and globally networked experimental music scene which emerged in Berlin in the mid-1990s. I was also responsible for the graphic design for this project while I was living in Berlin.
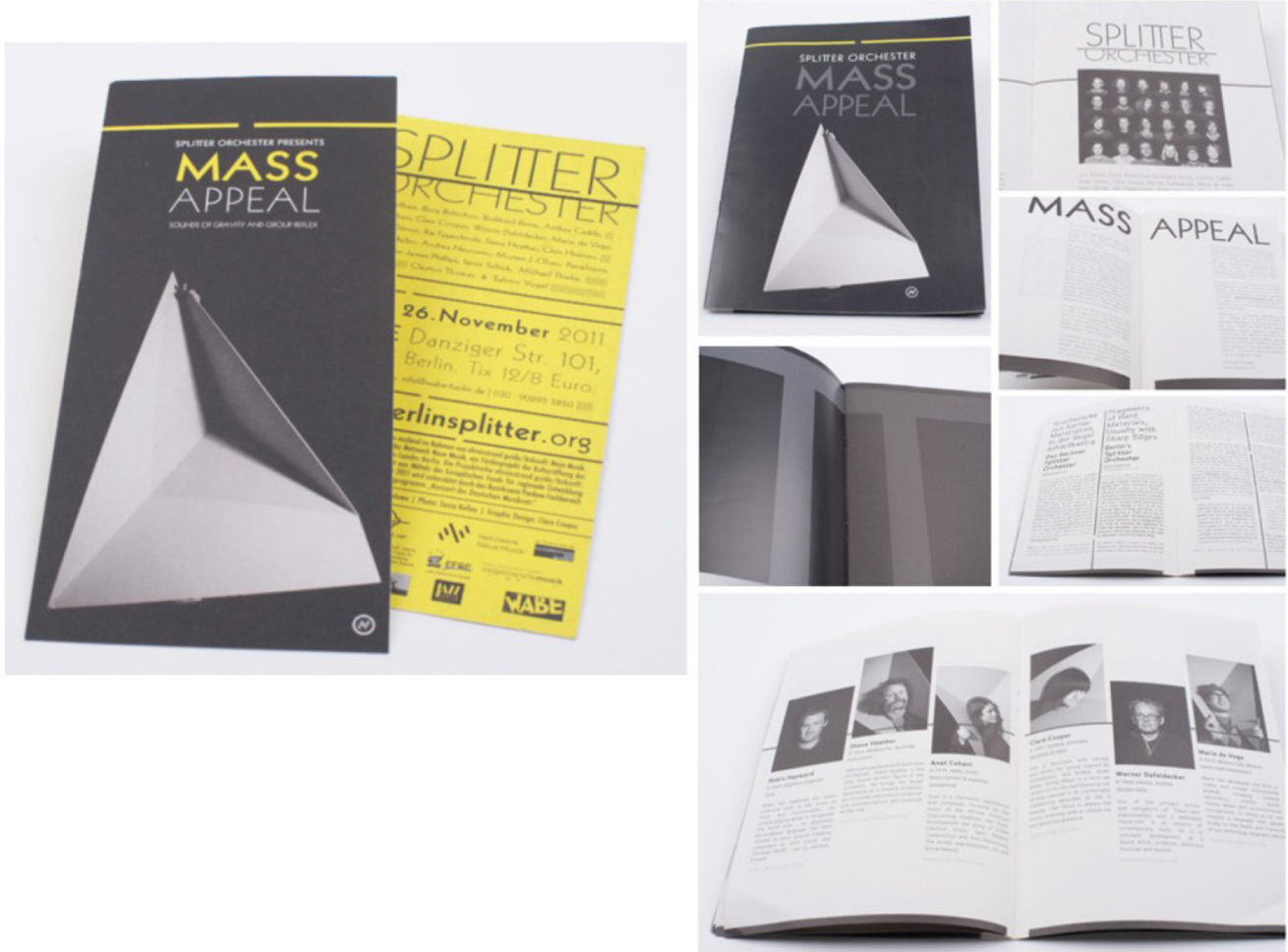

Figure 2 Publicity materials for Splitter Orchestra 2010-2012, design by Clare Cooper (c) Clare Cooper

I have just returned from a whirlwind ten days in central Java, where three Australian designers and Bali-based 'Bebe' (Sulaeman Akbar) were invited, as part of the Indonesian Australian Design Futures project, to engage with the sincere social design projects of Taring Padi, Bumi Langit, ViaVia, Warung Kita, Survive! Garage, Komunitas Tanam Untuk Kehudipan/SAPU Upcycle and Piranti Works/Spedagi. Each community shared something with us and some asked for our 'fresh eyes' (Singgih S. Kartono) and our feedback, and to 'borrow our wow' (Siska Callista).

I was particularly moved by the parallels between the political banners-improvisational creations of the Taring Padi collective and the experience of music making with long-term collaborative improvised music ensembles like Sydney's Splinter Orchestra or Berlin's Splitter Orchester. Taring Padi artist-turned-permaculture-farmer and teacher 'Bebe' shared stories of the early years of Taring Padi paste-ups and banner making (circa 1998-1999). They reclaimed public 
U T S

e P R E S S space as a canvas for their collective voice, using their unmistakable wood cut printing technique to raise awareness of police brutality, exploitative mining practice, water access and farming rights. The paste-ups altered the aesthetics of the Yogyakarta streets irreversibly in their ongoing political commentary, not to mention influencing the next generation of street artists and political activists.

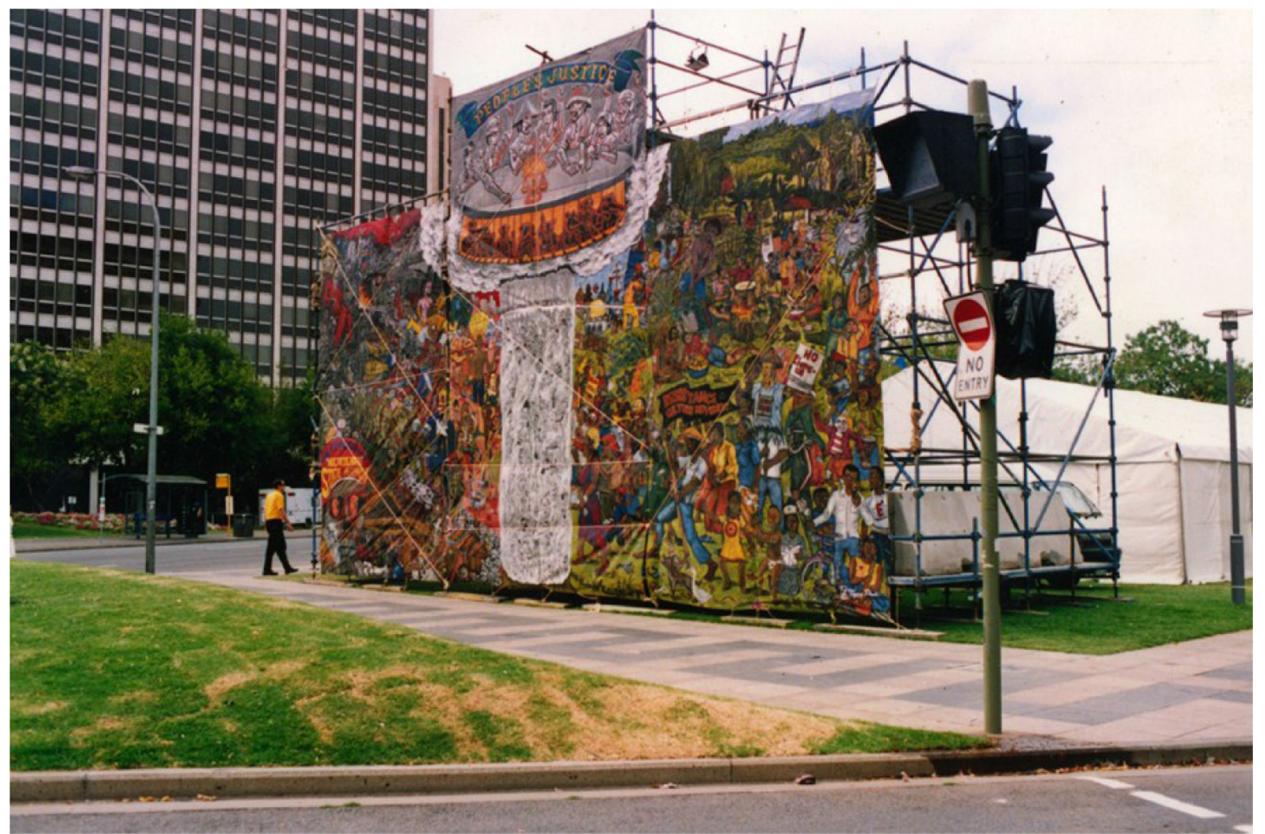

Figure 3 'People's Justice' by Taring Padi collective. Banner, acrylic on canvas, $800 \mathrm{~cm} \times 1200 \mathrm{~cm}$, Adelaide, 2002 @ Alexandra Crosby, 2002

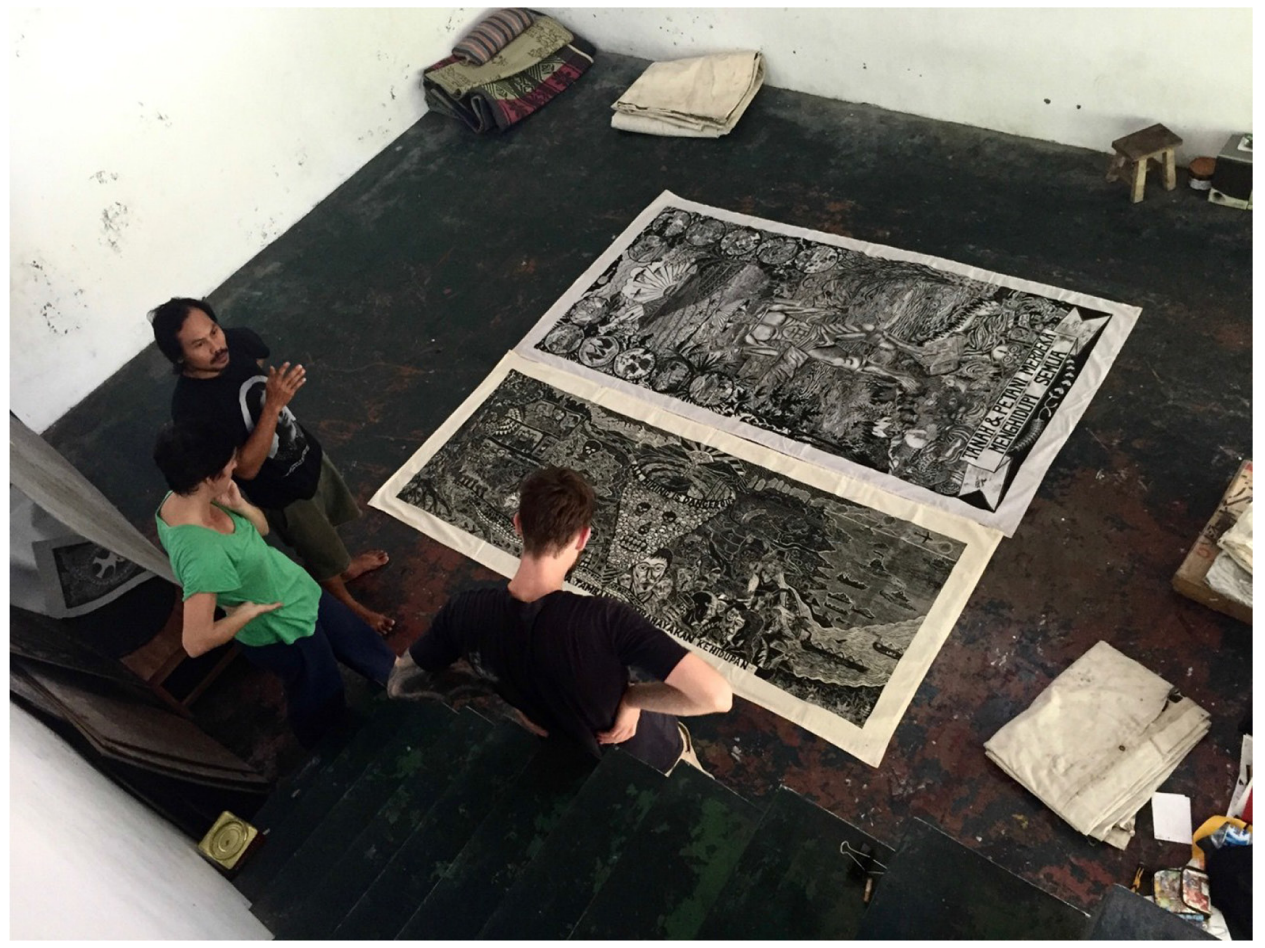

Figure 4 Taring Padi collective artist Djuwadi explains the technical and creative process for 'All Mining is Dangerous' and 'Tanah dan Petani Merdeka Menghidupi Semua' (c) Clare Cooper, 2016 
U T S

e P R E S S
Taring Padi artists recall many members of the collective waiting with poised brushes around the edges of a huge, blank canvas, waiting for someone to begin the story told by their collective image. Someone would begin and, like an explosion, the action would spread across the canvas. Armed with years of creating, arguing, appreciating and learning from one another, they trusted each other to be able to leave their individual artistic style at the edge, and to make a common statement, to tell a story or ask a question that each of them related to or wanted to fight for. This echoes my experience of that moment when the rustles and bustles of a room lulls in anticipation of a piece of music to begin.

Recalling my time with Berlin Splitter orchestra pieces often began with bold strokes; stabs from trumpet, electronic sine tones, drumsticks hitting the body of a double basscharacteristic of a group confident of its ability to co-create, to listen and be loud all at once. Improvising with the Splinter Orchestra in Sydney was more often than not an exercise in creative tentativity - as the line-up was often changing, many of our rehearsals and concerts were spent getting to know one another's voices. To play hard, loud and long was to deny others space. In his review of our first record release 'Playing Together' (Splitrec 2007) Bob Baker Fish suggests that 'even in those moments of restrained scratchy tranquility, you know that hiding behind it is a mountain of controlled mayhem ... It's a remarkable example of control, and whilst you could imagine it would be a nightmare to record, it feels like you can hear, even feel, every squeak and scrape' (Cyclic Defrost online 2007).

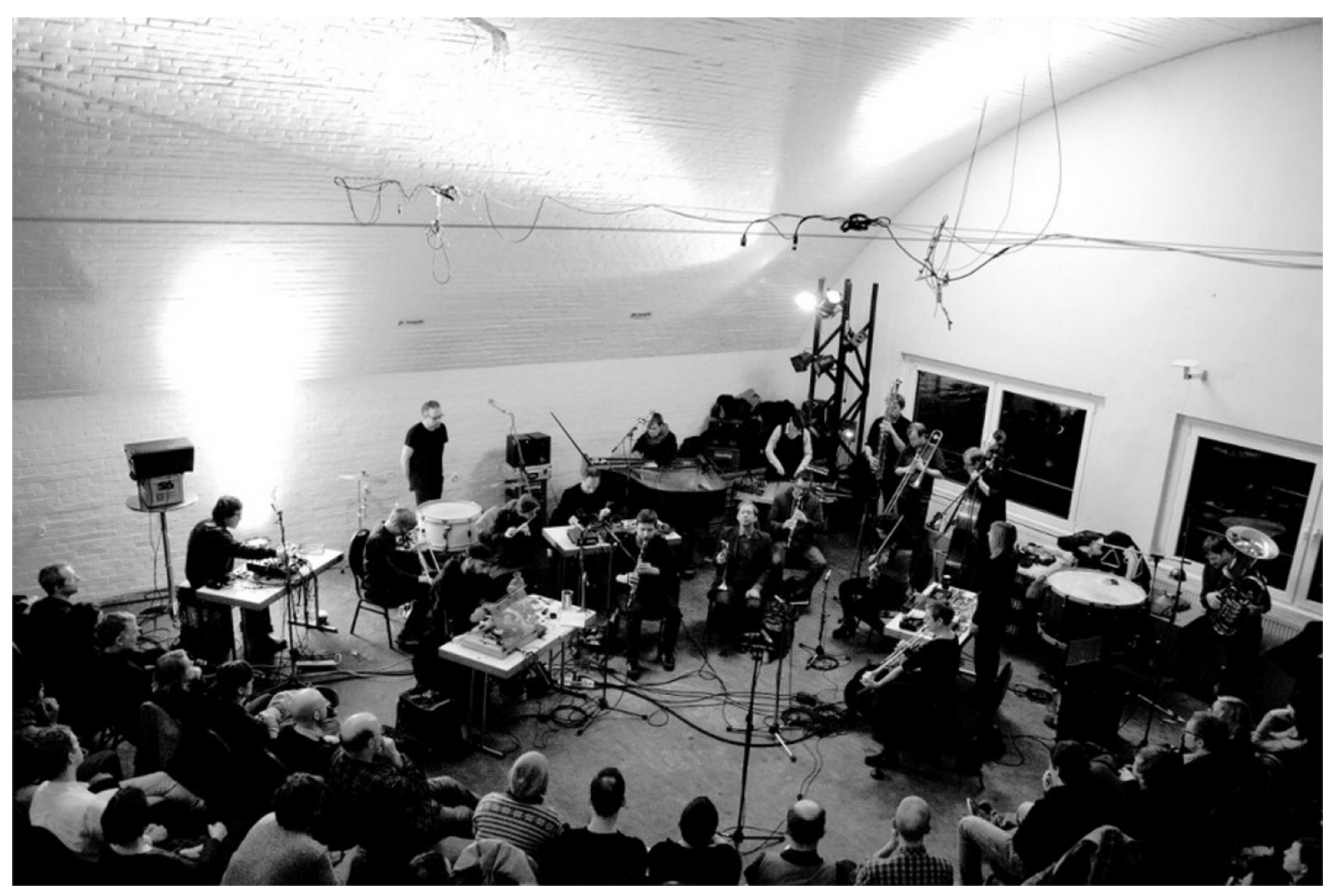

Figure 5 Splinter Orchestra, Berlin, the NOW now photo archive, 2014

In her book investigating socially-oriented art projects, Participation, Claire Bishop makes the point that 'on a technical level, most contemporary art is collectively produced (even if authorship often remains resolutely individual)' (Bishop 2006: 11). In collective improvisation we are active participants in the creation of our very own microcosmic social and political reality. We are collectively responsible for the outcomes and find that they often weigh in on equal measure with the process. Our ongoing creative dialogue with our collaborators and with the public is incredibly sensual, verbal, visual, textual and musical. 
U T S

e P R E S S

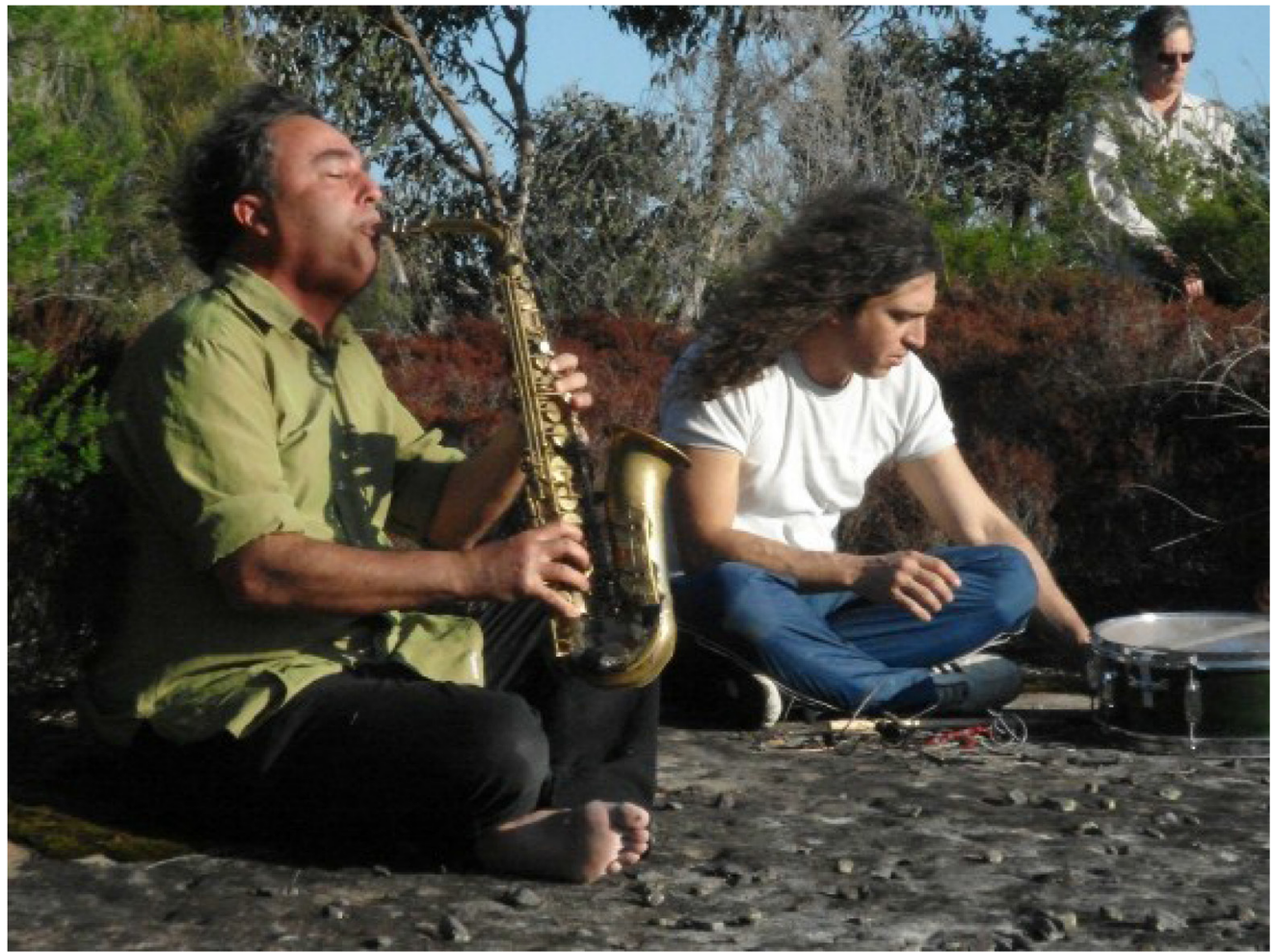

Figure 6 West Head Project performance, the NOW now photo archive, 2008

\section{References}

Baker Fish, B., 2007, 'The Splinter Orchestra: Review.' Cyclic Defrost. Online, available: http://www. cyclicdefrost.com/2007/09/the-splinter-orchestra-splitreccomau/ [accessed 28 June 2016]

Beins, B., Kesten, C., Nauck, G., \& Neumann, A. (eds) 2011, Echtzeitmusik Berlin. Hofheim, Wolke Bishop, C. 2006, Participation. London, Whitechapel

Kind, M., 2016, 'In Retrospect: 15 Years of Splinter Orchestra-The NOW Now 2016.' Online, available: https://vimeo.com/156369505 [accessed 28 June 2016] 